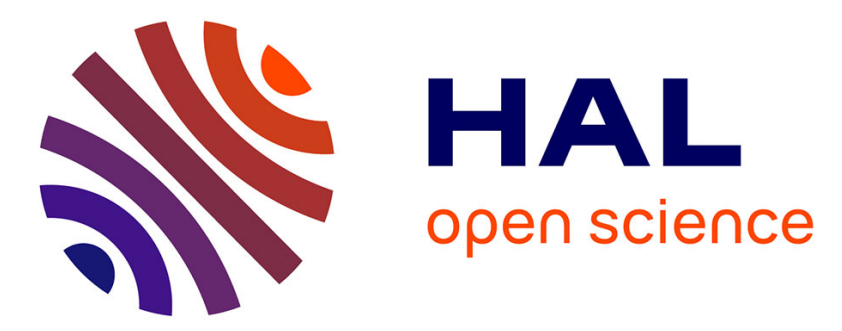

\title{
Mechanism of imazamox resistance of the Clearfield® wheat cultivar for better weed control
}

Antonia María Rojano-Delgado, Feliciano Priego-Capote, María Dolores

Luque de Castro, Rafael de Prado

\section{- To cite this version:}

Antonia María Rojano-Delgado, Feliciano Priego-Capote, María Dolores Luque de Castro, Rafael de Prado. Mechanism of imazamox resistance of the Clearfield® wheat cultivar for better weed control. Agronomy for Sustainable Development, 2015, 35 (2), pp.639-648. 10.1007/s13593-014-0232-7 . hal01284279

\section{HAL Id: hal-01284279 \\ https://hal.science/hal-01284279}

Submitted on 7 Mar 2016

HAL is a multi-disciplinary open access archive for the deposit and dissemination of scientific research documents, whether they are published or not. The documents may come from teaching and research institutions in France or abroad, or from public or private research centers.
L'archive ouverte pluridisciplinaire HAL, est destinée au dépôt et à la diffusion de documents scientifiques de niveau recherche, publiés ou non, émanant des établissements d'enseignement et de recherche français ou étrangers, des laboratoires publics ou privés. 


\section{Mechanism of imazamox resistance of the Clearfield ${ }^{\circledR}$ wheat cultivar for better weed control}

\author{
Antonia María Rojano-Delgado • Feliciano Priego-Capote • \\ María Dolores Luque de Castro • Rafael De Prado
}

Accepted: 15 May 2014 / Published online: 9 October 2014

(C) INRA and Springer-Verlag France 2014

\begin{abstract}
Wheat is a major world crop. Wheat production is actually decreased by the emergence of herbicide-resistant weeds commonly found in wheat fields. The need to control these weeds has led to the use of herbicides, such as imidazolinones, that are not typically used in wheat fields. As a consequence, a new wheat cultivar, the Clearfield ${ }^{\circledR}$ wheat Pandora variety, has been developed to be resistant to imidazolinones. Actually, only few mechanisms of resistance are known. Here, we studied non-target mechanisms and the resistance to imazamox for susceptible and resistant cultivars, under greenhouse and laboratory conditions. Our results show a resistance factor of 14.3. We observed that the acetolactate synthase enzyme in the resistant cultivar showed resistance to imazamox. We found also variable cross-resistance to all tested imidazolinone herbicides. Metabolism studies showed a high conversion of imazamox to two metabolites in the resistant cultivar. We also observed a similar penetration of imazamox in both cultivars and a high translocation of imazamox to the root in the susceptible cultivar. Results on cytochrome P450 suggest that the principal resistance mechanism is not in its metabolism. This is the first study on the metabolism of imazamox in Clearfield ${ }^{\circledR}$ wheat cultivars.
\end{abstract}

Keywords Triticum aestivum $\cdot$ Clearfield ${ }^{\circledR}$ crops $\cdot$ Imazamox . Resistance $\cdot$ Susceptibility $\cdot$ Metabolism $\cdot$ Cytochrome P450

A. M. Rojano-Delgado $(\bowtie) \cdot$ R. De Prado Department of Agricultural Chemistry, C-3 Building, Campus of Rabanales, and Agroalimentary Excellence Campus, ceiA3, University of Córdoba, 14071 Córdoba, Spain

e-mail: q92rodea@uco.es

F. Priego-Capote • M. D. Luque de Castro

Department of Analytical Chemistry, Annex C-3, Campus of Rabanales, and Agroalimentary Excellence Campus, ceiA3, University of Córdoba, 14071 Córdoba, Spain

\section{Introduction}

Because wheat, with a 2013 worldwide production of 656.42 million tons, is a crop that sustains the global economy, the losses occurring in this crop are reflected globally. The need to manage weeds resistant to herbicides widely used in wheat led to a search for new cultivars with mutations that could endow them with resistance to imidazolinones (Bond et al. 2005).

Imidazolinones have achieved great success in modern agriculture since they were developed in the 1970s. This success is a result of their high efficiency in cereal and legume crops, low mammalian toxicity with low environmental impact (Aichele and Penner 2005), wide crop selectivity and the large number of formulations suitable for pre- and postemergence applications (Shaner and O'Connor 1991).

The need to manage weeds resistant to herbicides widely used in wheat, corn, rice and other crops led to a search, starting in the 1990s, for new cultivars with mutations that could endow them with resistance to imidazolinones (Bond et al. 2005). The first variety found to have a mutation that conferred resistance to imazethapyr was a winter wheat known as "Fidel" (Anderson et al. 2004). The last induced resistance in wheat was to imazamox (Seefeldt et al. 1998), but it was not until 2000 that these crops began to be marketed under the name Clearfield ${ }^{\circledR}$. They were then considered to be an integrated form of weed control (Colquhoun et al. 2003) based on the development of varieties resistant to imidazolinones using traditional induction mutations and conventional breeding. This means that they are non-genetically modified seeds, thus increasing their success and value (Tan et al. 2005).

Imazamox [3-pyridinecarboxylic acid, 2-[4,5-dihydro-4methyl-4-(1-methylethyl)-5-oxo-1H-imidazol-2-yl]-5(methoxymethyl)-] is an imidazolinone that was first developed in 1998 (Brady et al. 1998). This herbicide is readily absorbed by leaves and roots. The primary mode of imazamox action is its inhibition of the acetolactate synthase enzyme (former E.C. 
4.1.3.18 and changed to E.C. 2.2.1.6 in 2002), which catalyses the first common step in the biosynthesis of branched chain amino acids such as valine, leucine and isoleucine in plants and microorganisms (Shaner and O'Connor 1991).

In 2010, Powles and Yu described the mechanism of acetolactate synthase enzyme inhibition by imazamox. This enzyme is formed by two subunits: one with a regulatory activity and one with a catalytic activity. The former stimulates the activity of the catalytic subunit and confers sensitivity to feedback inhibition of branched chain amino acids. The catalytic site of acetolactate synthase enzyme is located within a deep channel, and therefore, the acetolactate synthase enzyme-inhibiting herbicides do not bind directly to the catalytic site; rather, they bind by a binding domain to that site, which extends to the channel entry, allowing the herbicides to block the passage of the substrate to the catalytic site. Within this domain, 18 amino acid residues are involved in binding to the herbicide. Structurally different acetolactate synthase enzyme-inhibiting herbicides are oriented differently in herbicide-binding domains, with partial overlap (Duggleby et al. 2008). Therefore, a mutation that causes an amino acid substitution inside the binding domain may confer resistance to some herbicides, but not to others (Kolkman et al. 2004), or even to several herbicides with the same mode of action causing cross-resistance (Han et al. 2012). Five mutations of the acetolactate synthase enzyme gene have been described in the amino acid positions Ala122, Pro197, Ala205, Trp574 and Ser653 (Tan et al. 2005). The mutation at Trp574 confers cross-resistance to all acetolactate synthase enzymeinhibiting herbicide families. The Pro197 codon mutation confers a high resistance to sulfonylureas. Mutations at codons Ala122, Ala205 and Ser653 confer resistance to imidazolinones; Ala122 confers higher levels of resistance to imidazolinones than mutation Ser653 ( $\mathrm{Li}$ et al. 2008). Recently, a mutation at position Ser-Asn627 has shown itself to be responsible for resistance in Tritordeum (RodríguezSuárez et al. 2009). As the mutated imidazolinoneresistant acetolactate synthase enzyme genes are semidominant, increased resistance could be a consequence of two or more resistance genes in a given genotype (Pozniak and Hucl 2004).

Enhanced metabolism of imidazolinones has been studied in Myriophyllum spicatum, soybean, alfalfa and leguminous crops (Bukun et al. 2012; Ohba et al. 1997) but never in Clearfield ${ }^{\circledR}$ wheat. Different metabolic pathways may be involved depending on the ring structure (pyridine, benzene or quinolone) and substituents of a given herbicide. In resistant species, imazamox metabolism occurs by oxidative hydroxylation at the $\alpha$ carbon of the 5-methoxymethyl substituent on the pyridine ring, followed by carbohydrate conjugation (Ohba et al. 1997). Sensitive species metabolise this herbicide either slowly or not at all. Studies by Fischer et al.
(2000) using cytochrome P450 monooxygenase inhibitors (EC 1.14.14.1, P450s) showed that P450 is a mediator of herbicide degradation involved in multiple resistance. Assays with specific P450 inhibitors, such as organophosphate insecticides, applied together with some herbicides enhanced injury to resistant biotypes, demonstrating that these isozymes belong to the most important enzymatic system involved in the first phase of herbicide metabolism by some plants (WerckReichhart et al. 2000). One of these organophosphate insecticides is malathion, which releases atomic sulphur inhibiting P450 apoprotein (Werck-Reichhart et al. 2000). Acetolactate synthase herbicides can be P450 inducers or inhibitors because they act as P450 substrates in phase I of metabolism.

Various studies of plant resistance to imazamox have been carried out on enzymatic activity (Rainbolt et al. 2005), absorption/translocation (Bukun et al. 2012) and metabolism (Bukun et al. 2012; Ohba et al. 1997). Metabolism studies have been conducted using ${ }^{14} \mathrm{C}$ imazamox to determine some metabolites based on radioactivity measurements, although the measured signal can also be due to degradation products of nonmetabolic herbicide pathways (Harir et al. 2007). More convincing are the results of the work by Ohba et al. (1997), who identified two metabolites of imazamox in adzuki beans (Vigna angularis) using standards of both metabolites synthesised by the American Cyanamid Company (Ohba et al. 1997).

The wheat market is of great relevance in the global agricultural economy, both because of the great extent of cultivation and the growing number of farms devoted to this crop. The Pandora wheat cultivar (Triticum aestivum), which is resistant to imazamox, has been used in Chile as an effective way to control a large number of weeds resistant to herbicides. The aim of our research was to study the resistance mechanisms, including the metabolism of imazamox of two cultivars of T. aestivum var. Pandora (Mellado and Madariaga 2003) with different degrees of resistance to imazamox (Fig. 1). This will be the first time that the metabolism of imazamox will be studied in cultivars of this type. The absence of any commercial standards of imazamox metabolites promoted the development of a method for the determination of the precursor and metabolites based on liquid chromatography-absorptiometry detection by a diode array detector prior to the identification of the target analytes by liquid chromatography-time-of-flight mass spectrometry in high-resolution mode. Thus, the difference between the metabolisms of both cultivars can be checked by verifying whether metabolism is in fact a key mechanism of resistance in Clearfield ${ }^{\circledR}$ crops or whether there are other more significant mechanisms. 


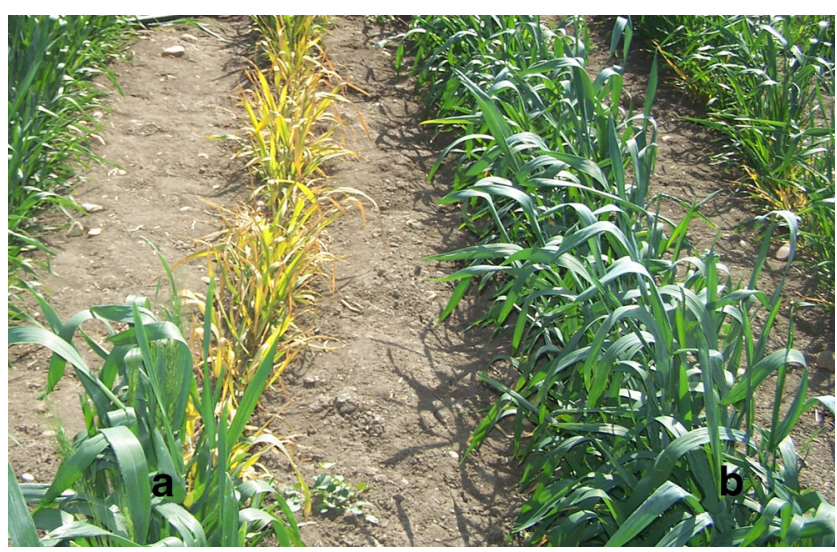

Fig. 1 Wheat plants treated with imazamox at $40 \mathrm{~g}$ ai ha ${ }^{-1}$. a Conventional Pandora wheat. b Pandora Clearfield ${ }^{\circledR}$ wheat. This image shows how the resistant cultivar is capable of withstanding a normal field dose without any damage compared to the conventional cultivar which is seriously damaged; this suggests that the resistant cultivar can be used as a new tool for control of weeds

\section{Materials and methods}

\subsection{Plants and growing conditions}

Two cultivars of $T$. aestivum var. Pandora with different degrees of resistance to imazamox were used for comparative purposes. Seeds of the two cultivars of wheat (spring type) were obtained from plants grown in Chile (INIA Carillanca) (Mellado and Madariaga 2003). The seeds were germinated in pots of $346 \mathrm{~cm}^{2}$ (three plants per pot) containing peat and sandy loam potting mixture $(1: 2, v / v)$ in a growth chamber at $28 / 18{ }^{\circ} \mathrm{C}$ (day/night) with a 16 -h photoperiod under $850 \mu \mathrm{mol} \mathrm{m} \mathrm{m}^{-2} \mathrm{~s}^{-1}$ photosynthetic photon flux density and $80 \%$ relative humidity (day/night).

\subsection{Dose-response assays}

Treatment with imazamox (PULSAR 40, BASF) was applied at the 5- to 6-leaf stage in both cultivars by using a laboratory track sprayer furnished with a Tee Jet 80.02.E.VS flat fan nozzle and delivering a spray volume of $200 \mathrm{l} \mathrm{ha}^{-1}$ at $200 \mathrm{kPa}$. Imazamox was applied at doses of $0,10,20,30$, 40,50 and $60 \mathrm{~g}$ of active ingredient (ai) $\mathrm{ha}^{-1}$ to the susceptible cultivar and at doses of $0,50,100,200,300,400,500,600$ and $800 \mathrm{~g}$ ai ha ${ }^{-1}$ to the resistant cultivar. Aboveground fresh weight per pot was determined 21 days after spraying, and the data were expressed as percentages of the values for the corresponding control (untreated plants). The effective dose needed to inhibit plant growth of each cultivar by $50 \%$ with respect to the untreated control $\left(\mathrm{ED}_{50}\right)$ was determined according to González-Torralva et al. (2014). The resistance/ susceptibility ratio was computed as $\mathrm{ED}_{50}$ (resistant cultivar)/ $\mathrm{ED}_{50}$ (susceptible cultivar) in terms of fresh weight. Experimental treatments were replicated five times, and each test was conducted four times. The data were pooled and fitted to a non-linear log-logistic regression model, using the equation $Y=c+\left\{(d-c) /\left[1+(x / g)^{b}\right]\right\}$, where $Y$ is the fresh aboveground weight expressed as a percentage of the untreated control, $c$ and $d$ are coefficients corresponding to the lower and upper asymptotes, $b$ is the slope of the curve, $g$ is the herbicide rate at the point of inflection halfway between the upper and lower asymptotes and $x$ (independent variable) is the herbicide rate. Regression analysis was conducted by using SigmaPlot 10.0 statistical software according to CruzHipólito et al. (2009).

\subsection{Growth assays in the presence of imazamox with malathion}

Seedlings at the 2-3-leaf stage were treated with imazamox at doses of $0,10,20,30,40,50$ and $60 \mathrm{~g}^{\text {ai }} \mathrm{ha}^{-1}$ to the susceptible cultivar and of $0,50,100,200,300,400,500$, 600 and $800 \mathrm{~g} \mathrm{ai} \mathrm{ha}^{-1}$ to the resistant cultivar, each dose rate with malathion at $1,000 \mathrm{~g}$ ai ha ${ }^{-1}$ and each without malathion. Malathion was applied $1 \mathrm{~h}$ before imazamox application. A non-treated control for each cultivar was also included. Sprayer configuration and growth conditions were similar to those in the experiments mentioned previously. Plants were harvested at the same time as in the dose-response assay, and the statistical methods were also similar.

\subsection{Assay of acetolactate synthase enzyme activity}

The acetolactate synthase enzyme response to acetolactate synthase enzyme-inhibiting herbicides was determined in vitro using crude extracts isolated from $\mathrm{R}$ and $\mathrm{S}$ cultivar leaves, as described by Osuna and De Prado (2003). Leaf tissue $(3 \mathrm{~g})$ from plants at the 3- to 5-leaf stage was frozen with liquid $\mathrm{N}_{2}$ and ground to a fine powder, after which $0.5 \mathrm{~g}$ of polyvinylpyrrolidone was added. The extraction employed an extraction buffer and a 1:2 tissue-buffer ratio; the buffer composition was as follows: $1 \mathrm{M} \mathrm{K}$-phosphate buffer solution (pH 7.5), $10 \mathrm{mM}$ sodium pyruvate, $5 \mathrm{mM} \mathrm{MgCl}_{2}, 50 \mathrm{mM}$ thiamine pyrophosphate, $100 \mu \mathrm{M}$ flavin adenine dinucleotide, $12 \mathrm{mM}$ dithiothreitol and in 1:9 $(\mathrm{v} / \mathrm{v})$ glycerol-water. The suspension was agitated for $10 \mathrm{~min}$ at $4{ }^{\circ} \mathrm{C}$. The homogenate was filtered through four layers of cheesecloth and centrifuged $(20,000 \mathrm{~g}$ for $20 \mathrm{~min})$. The supernatant contained a crude acetolactate synthase enzyme, which was immediately used for the enzyme assays.

The acetolactate synthase enzyme activity was assayed by adding $90 \mu \mathrm{l}$ of enzyme extract to $110 \mu \mathrm{l}$ of freshly prepared assay buffer (0.08 M K-phosphate buffer solution [pH 7.5], $0.5 \mathrm{M}$ sodium pyruvate, $0.1 \mathrm{M} \mathrm{MgCl}_{2}, 0.5 \mathrm{mM}$ thiamine pyrophosphate and $1,000 \mu \mathrm{M}$ flavin adenine dinucleotide) containing increased concentrations of technical grade imazamox (Sigma-Aldrich, St. Louis, USA). A solution of 
$0.04 \mathrm{M} \mathrm{K}_{2} \mathrm{HPO}_{4}(\mathrm{pH}$ 7.0) was added to a final volume of $250 \mu$ l. The mixture was incubated at $37^{\circ} \mathrm{C}$ for $1 \mathrm{~h}$, and the reaction was stopped by adding $50 \mu \mathrm{l}$ of $\mathrm{H}_{2} \mathrm{SO}_{4}$ /water $1: 10(v / v)$. The reaction tubes were then heated for $15 \mathrm{~min}$ at $60{ }^{\circ} \mathrm{C}$ to decarboxylate acetolactate to acetoin, which was determined as a coloured complex $\left(\mathrm{A}_{520} \mathrm{~nm}\right)$ formed after the addition of $250 \mu \mathrm{l}$ of creatine $\left(5 \mathrm{~g} \mathrm{l}^{-1}\right.$ freshly prepared in water) and $250 \mu \mathrm{l}$ of 1-naphthol (50 $\mathrm{g} \mathrm{l}^{-1}$ freshly prepared in $5 \mathrm{~N} \mathrm{NaOH}$ ) prior to incubation at $60{ }^{\circ} \mathrm{C}$ for $15 \mathrm{~min}$. The background was subtracted using control tubes in which the reaction was stopped prior to incubation.

In addition to imazamox, other imidazolinone herbicides (imazethapyr, imazaquin, imazethabenz-methyl and imazapyr) were used to study the possible cross-resistance to this class of herbicides; these herbicides were applied following the protocol described for imazamox. The concentration of herbicide that causes a $50 \%$ reduction in acetolactate synthase enzyme activity $\left(\mathrm{I}_{50}\right)$ was measured in plants treated with the different herbicides and was used for the resistant/susceptible ratio calculated as $\mathrm{I}_{50}$ (resistant) $/ \mathrm{I}_{50}$ (susceptible). Total protein content was determined by the Bradford method (Bradford 1976), based on measurement of the absorbance at $595 \mathrm{~nm}$ of an acidic solution of Coomassie Brilliant Blue G-250 after binding to proteins. The maximum acetolactate synthase enzyme-specific activity (nanomoles of acetoin per milligram of protein per hour) was measured in the absence of the herbicide, and the data were pooled and fitted to the loglogistic model (Seefeldt et al. 1995). The experiment was performed in triplicate for each concentration of the herbicide.

\subsection{Metabolism of imazamox}

The methodology described by Rojano-Delgado et al. (2013) was followed in this study.

Application of imazamox was performed as dose-response assays with a relative volume of $2001 \mathrm{ha}^{-1}$ and with three doses of imazamox at 50, 100 and $200 \mathrm{~g}_{\text {ai ha }}{ }^{-1}$ (corresponding to one, two and four times the average dose used in field) as well as a 0 dose (control). Plants - both those treated with herbicide and the controls-were cut $0,48,72,96$ and $120 \mathrm{~h}$ after application and stored at $-40{ }^{\circ} \mathrm{C}$ until use. Before extraction, the frozen samples were washed with $60 \mathrm{ml}$ of water to remove traces of imazamox and soil on the leaf surface; they were then placed in a porcelain mortar and ground to a fine powder using liquid nitrogen.

One-half gram of each sample was mixed with $10 \mathrm{ml}$ 90:10 $(v / v)$ methanol-water and extracted using ultrasound and applied at $70-\mathrm{W}$ ultrasonication power for $10 \mathrm{~min}$ (duty cycle $0.7 \mathrm{~s} \mathrm{~s}^{-1}$ ), after which the solid residue was removed by centrifugation ( $15 \mathrm{~min}$ at 2,900g). Then, $6 \mathrm{ml}$ of this extract was taken and evaporated to dryness under an air stream. The solid residue was reconstituted by $0.5 \mathrm{ml}$ of extractant $(90: 10$ methanol-water) and filtered through a nylon filter syringe
(45- $\mu \mathrm{m}$ pore size and $13 \mathrm{~mm}$ i.d. from Millipore, Carrigtwohill, Ireland) before chromatographic analysis.

The same chromatographic method was used for the identification of imazamox metabolites employing a liquid chromatography-time-of-flight/mass spectrometer arrangement. For the determination of imazamox and its metabolites in extracts from plants, a liquid chromatography-diode array detector was employed. A hydrophilic interaction liquid chromatography column $(20 \mathrm{~cm} \times$ $4.6 \mathrm{~cm}, 3-\mu \mathrm{m}$ particle size) was used for the separation of the target compounds in both cases. Fifty microlitres of the reconstituted phase was injected into the liquid chromatography with $1 \%(v / v)$ acetic acid in water as mobile phase A and pure methanol as mobile phase B. The elution program started with $5 \%$ mobile phase B and followed the linear gradient: step 1, 5 to $20 \%$ methanol in $10 \mathrm{~min}$; step 2,20 to $80 \%$ methanol in $10 \mathrm{~min}$; step 3, 80 to $100 \%$ methanol in $5 \mathrm{~min}$; and step 4, 100 to $5 \%$ methanol in $10 \mathrm{~min}$. The constant flow rate and column temperature were $1.0 \mathrm{ml} \mathrm{min}^{-1}$ and $40{ }^{\circ} \mathrm{C}$, respectively. Chromatographic grade and liquid chromatography-mass spectrometer grade solvents were used for liquid chromatography-diode array detector and liquid chromatography-time-of-flight/mass spectrometer analysis, respectively.

dentification of the metabolites was conducted by liquid chromatography-time-of-flight/mass spectrometer confirmatory analysis in accurate mode owing to the complexity of plant extracts. The analyses were performed in an Agilent 1200 Series LC system interfaced to an Agilent 6540 UHD Accurate-Mass liquid chromatography-time-of-flight/mass spectrometer detector (Palo Alto, USA), equipped with an Agilent Jet Stream Technology electrospray ion source operating in the positive ionisation mode. The separation conditions were identical to those for the liquid chromatographydiode array detector determination, except for the use of the respective liquid chromatography-time-of-flight/mass spectrometer grade solvents.

After identification and confirmatory analysis by liquid chromatography-time-of-flight/mass spectrometer, imazamox and metabolites were determined by the liquid chromatography-diode array detector analysis (measurement wavelength, $240 \mathrm{~nm}$ ). A 15 Gold HPLC System from Beckman Coulter (Fullerton, USA) equipped with a 26 System Gold Diode Array detector (wavelength range 190 $600 \mathrm{~nm}$ ) was used in this case. Chromatographic peaks in the liquid chromatography-diode array detector were assigned according to retention times using as a reference the imazamox peak identified by spiking extracts with the commercial standard. Quantification of imazamox metabolites was based on the calibration model for imazamox, and the results were expressed as micrograms $(\mu \mathrm{g})$ of the analyte 
equivalent to imazamox per gram $\left(\mathrm{g}^{-1}\right)$ of plant. The obtained calibration equation for imazamox was as follows:

$Y=1.967+93.003 * X$

where $Y$ is expressed as the absorbance units $10^{-3}$ and $X$ as micrograms per millilitre $\left(\mu \mathrm{g} \mathrm{ml}^{-1}\right)$.

The limit of detection was $0.081 \mu \mathrm{g} \mathrm{l}^{-1}$, and the limit of quantitation was $0.270 \mu \mathrm{g} \mathrm{l}^{-1}$, together with the obtained recovery data; these values were the same as in those in the method of Rojano-Delgado et al. (2013).

Comparison of the results obtained by liquid chromatography-time-of-flight/mass spectrometer and liquid chromatography-diode array detector was performed by using seven plants and three replications per sample.

\subsection{Imazamox metabolism in combination with malathion}

Seedlings of resistant and susceptible cultivars at the 2-3-leaf stage were treated with imazamox at doses of $200 \mathrm{~g}$ ai ha ${ }^{-1}$, in a mixture with malathion at $1,000 \mathrm{~g} \mathrm{ha}^{-1}$ and without malathion. Malathion was applied $1 \mathrm{~h}$ prior to imazamox application. An untreated control for each cultivar was also included. They were harvested $96 \mathrm{~h}$ after treatment. The sprayer configuration and growth conditions were similar to experiments commented on previously. Plants were harvested at the same time as the dose-response assay, and the statistical study was also similar.

\subsection{Methods of statistics}

Data were processed using STATGRAPHICS Plus (v. 4.0; STATGRAPHICS, Warrenton, VA, USA). Simple analysis of variance (ANOVA) and simple linear regression were used.

\section{Results and discussion}

\subsection{Dose-response assays}

The application of imazamox (without malathion) on Pandora plants reduced shoot biomass production in both the resistant and susceptible cultivars. The $\mathrm{ED}_{50}$ (herbicide concentration required for a $50 \%$ reduction of plant fresh weight) for the resistant cultivar was 314.9 versus $22.0 \mathrm{~g}$ ai ha ${ }^{-1}$ for the susceptible cultivar (Table 1). These results, obtained from the whole plant dose-response bioassay, showed that the resistant cultivar was 14.3 times more resistant to imazamox than the susceptible cultivar; therefore, the resistant cultivar proved to be highly resistant to imazamox, in agreement with the data reported by Mellado and Madariaga (2003).
3.2 Growth assays in the presence of imazamox with malathion

Treatment of imazamox (with and without malathion) presented a similar $\mathrm{ED}_{50}$ behaviour in the susceptible cultivar (Table 1).

In the resistant cultivar, the difference between the $\mathrm{ED}_{50}$ of the two treatments with imazamox (with and without malathion) showed a difference by approximately $27 \%$, greater for treatment without malathion (Table 1). This behaviour suggests that the resistance is mainly due to other mechanisms (different from imazamox metabolism), in which cytochrome P450 is not involved; therefore, the metabolism mechanism only enhances resistance to this herbicide but does not determine it.

\subsection{Acetolactate synthase enzyme activity assays}

The specific in vitro activity of the acetolactate synthase enzyme obtained from shoot Pandora tissue was similar in resistant and susceptible cultivars $(279.3 \pm 11.5$ and $284.0 \pm$ $27.9 \mathrm{nmol}$ of acetoin per milligram of protein per hour, respectively).

The $\mathrm{I}_{50}$ values for the different herbicides are shown in Table 2. In all cases, the acetolactate synthase in the resistant cultivar tolerated higher concentrations of herbicide than its susceptible counterpart. The order of the resistance factors estimated by the acetolactate synthase enzyme in vitro assay to different imidazolinone herbicides was imazamox $>$ imazethabenz-methyl $\approx$ imazapyr $>$ imazaquin $>$ imazethapyr (Table 2). These resistance factors show cross-resistance to imidazolinones, especially with regard to imazamox and imazethabenz-methyl. This behaviour suggests, as a resistance mechanism, an alteration of the acetolactate synthase enzyme produced by a mutation causes the loss of affinity for the binding site (Han et al. 2012) in the resistant cultivar. This mechanism was discussed in different cultivars of wheat and Tritordeum, where the most important mutations were Ala122 and Ser627 ( $\mathrm{Li}$ et al. 2008; Rodríguez-Suárez et al. 2009). Both mutations can occur simultaneously, thus conferring higher resistance (Pozniak and Hucl 2004).

\subsection{Metabolism of imazamox}

Two imazamox metabolites, hydroxy and glucoside derivatives, were accurately identified in extracts from resistant cultivars by liquid chromatography-time-of-flight/mass spectrometer, as shown in Table 3 and in Fig. 2a. Figure 2b shows, overlapped, the extracted ion chromatograms (EICs) obtained by monitoring the precursor ions at $\mathrm{m} / \mathrm{z} 454.1820,292.1292$ and 306.1448 corresponding to $[\mathrm{M}+\mathrm{H}]^{+}$adducts with theoretical formulas $\mathrm{C}_{20} \mathrm{H}_{27} \mathrm{~N}_{3} \mathrm{O}_{9}, \mathrm{C}_{14} \mathrm{H}_{17} \mathrm{~N}_{3} \mathrm{O}_{4}$ and $\mathrm{C}_{15} \mathrm{H}_{19} \mathrm{~N}_{3} \mathrm{O}_{4}$, respectively. The first peak was identified as 3pyridinecarboxylic acid, 2-[4,5-dihydro-4-methyl-4-(1- 
Table 1 Parameters of the log-logistic equation \pm standard deviation (SD) used to calculate the imazamox effective doses required for a $50 \%$ reduction of fresh weight $\left(\mathrm{ED}_{50}\right)$ in both cultivars of Triticum aestivum var. Pandora with and without malathion (cytochrome P450 inhibitor)

\begin{tabular}{lllllll}
\hline Cultivar & Malathion & $c$ & $d$ & $b$ & $\mathrm{ED}_{50}{ }^{\mathrm{a}}$ & $\mathrm{RF}^{\mathrm{c}}$ \\
\hline Susceptible & - & $-10.2 \pm 5.47$ & $101.4 \pm 7.67$ & $2.5 \pm 0.46$ & $22.0 \pm 1.15$ & $<0.001$ \\
Resistant & & $-14.7 \pm 7.42$ & $102.7 \pm 2.16$ & $2.1 \pm 0.26$ & $314.9 \pm 2.82$ & $<0.001$ \\
Susceptible & + & $-4.0 \pm 3.02$ & $92.1 \pm 4.73$ & $3.2 \pm 0.50$ & $21.3 \pm 0.84$ & $<0.001$ \\
Resistant & & $-9.9 \pm 3.63$ & $100.5 \pm 1.73$ & $2.3 \pm 0.60$ & $230.2 \pm 1.99$ & $<0.001$ \\
\hline
\end{tabular}

Equation $Y=c+\left\{(d-c) /\left[1+(x / g)^{b}\right]\right\}$, where $Y$ is the percent plant injury; $x$ (independent variable) is the herbicide rate; $c$ and $d$ are the lower and upper asymptotes, respectively; and $b$ is the slope of the curve. Data were pooled and fitted to a nonlinear regression model. All values were calculated by mean average of five replicates repeated four times

$E D_{50}$ the effective dose required for $50 \%$ plant injury

${ }^{\mathrm{a}}$ Expressed as grams of active ingredient per hectare $\left(\mathrm{g}\right.$ ai ha $\left.{ }^{-1}\right)$

${ }^{\mathrm{b}}$ Probability level of significance of the nonlinear model

${ }^{\mathrm{c}}$ Resistance factor $(\mathrm{RF})=\mathrm{ED}_{50}$ of resistant $/ \mathrm{ED}_{50}$ of susceptible cultivar

methylethyl)-5-oxo-1H-imidazol-2-yl]-5-[( $\beta-D-$ glucopyranosyloxy)methyl]-(glucose-conjugated metabolite), associated with the ion $[\mathrm{M}+\mathrm{H}]+$ with $m / z$ 454.1817; the second eluted compound was identified as 3-pyridinecarboxylic acid, 2-[4,5-dihydro-4-methyl-4-(1-methylethyl)-5-oxo-1Himidazol-2-yl]-5-(hydroxymethyl)-(hydroxylated metabolite), associated with the ion $[\mathrm{M}+\mathrm{H}]+$ with $m / z 292.1295$; and the third compound was the 3-pyridinecarboxylic acid, 2-[4,5dihydro-4-methyl-4-(1-methylethyl)-5-oxo-1H-imidazol-2yl]-5-(methoxymethyl)-(imazamox), associated with the ion $[\mathrm{M}+\mathrm{H}]+$ with $\mathrm{m} / \mathrm{z} 306.1454$.

Once the compounds and their retention times were known (the latter being $16.02 \pm 0.28 \mathrm{~min}$ for the glucose-conjugated metabolite, $16.83 \pm 0.12 \mathrm{~min}$ for the hydroxylated metabolite, and $19.06 \pm 0.10 \mathrm{~min}$ for imazamox), the results obtained by the liquid chromatography-diode array detector showed a clear difference between cultivars, with respect to exposure time and different doses used (Table 3).

The first difference found was in the amount of imazamox which had been metabolised, which was only found in the resistant cultivar (as evidenced by the presence of the metabolites). The time and doses used were factors which affected the metabolism (Table 3). Metabolism seems to be induced by the amount of imazamox applied, as it is activated at higher dose and occurred earlier, as is shown at dose $200 \mathrm{~g}$. The percentage of metabolised imazamox can be calculated by considering that all metabolites come from imazamox and taking the sum of all of them as $100 \%$ (imazamox +hydroxylated metabolite + glucose-conjugated metabolite $=100 \%$ ). Approximately $67.74 \%$ of imazamox $\left(224.25 \mu \mathrm{g} \mathrm{g}^{-1}\right.$ of fresh

Table 2 Parameters of the equation \pm standard deviation (SD) used to calculate the herbicide concentration required for $50 \%$ reduction of the ALS activity $\left(\mathrm{I}_{50}\right)$ of resistant $(\mathrm{R})$ and susceptible $(\mathrm{S})$ cultivars of Triticum aestivum var. Pandora

\begin{tabular}{|c|c|c|c|c|c|c|c|c|}
\hline Herbicides $(\mu \mathrm{M})$ & $\mathrm{cv}$ & $c$ & $d$ & $b$ & $\mathrm{I}_{50}(\mu \mathrm{M})$ & Pseudo $R$ & $P$ value & $\mathrm{RF}$ \\
\hline \multirow[t]{2}{*}{ Imazamox } & Susceptible & $0.964 \pm 0.087$ & $100.242 \pm 2.560$ & $0.387 \pm 0.012$ & $1.469 \pm 0.094$ & 0.978 & $<0.0001$ & \\
\hline & Resistant & $13.802 \pm 1.639$ & $100.785 \pm 1.479$ & $1.023 \pm 0.074$ & $378.002 \pm 10.285$ & 0.998 & $<0.0001$ & 257.319 \\
\hline \multirow[t]{2}{*}{ Imazethapyr } & Susceptible & $0.120 \pm 0.032$ & $99.873 \pm 1.993$ & $0.976 \pm 0.028$ & $0.989 \pm 0.031$ & 0.975 & $<0.0001$ & \\
\hline & Resistant & $3.361 \pm 0.585$ & $100.045 \pm 2.002$ & $0.459 \pm 0.020$ & $6.514 \pm 0.947$ & 0.982 & $<0.0001$ & 6.586 \\
\hline \multirow[t]{2}{*}{ Imazaquin } & Susceptible & $0.286 \pm 0.091$ & $100.228 \pm 1.386$ & $2.834 \pm 0.371$ & $1.347 \pm 0.018$ & 0.980 & $<0.0001$ & \\
\hline & Resistant & $6.279 \pm 0.863$ & $100.146 \pm 1.935$ & $0.907 \pm 0.026$ & $12.464 \pm 1.243$ & 0.989 & $<0.0001$ & 9.253 \\
\hline \multirow[t]{2}{*}{ Imazethabenz-methyl } & Susceptible & $4.745 \pm 0.996$ & $101.005 \pm 1.044$ & $2.830 \pm 0.028$ & $1.281 \pm 0.054$ & 0.977 & $<0.0001$ & \\
\hline & Resistant & $9.285 \pm 1.045$ & $97.269 \pm 3.532$ & $3.531 \pm 0.064$ & $317.120 \pm 15.280$ & 0.998 & $<0.0001$ & 247.56 \\
\hline \multirow[t]{2}{*}{ Imazapyr } & Susceptible & $8.442 \pm 1.004$ & $99.998 \pm 2.473$ & $1.048 \pm 0.037$ & $3.842 \pm 0.165$ & 0.995 & $<0.0001$ & \\
\hline & Resistant & $0.779 \pm 0.056$ & $100.697 \pm 1.787$ & $0.656 \pm 0.025$ & $315.056 \pm 15.936$ & 0.994 & $<0.0001$ & 82.003 \\
\hline
\end{tabular}

Equation $Y=c+\{(d-c) /[1+(x / g) b]\}$, where $Y$ is the percentage of plant injury, $x$ (independent variable) is the herbicide concentration, $c$ and $d$ are the lower and upper asymptotes, respectively, and $b$ is the slope of the line. Data were pooled and fitted to a nonlinear regression model

$I_{50}$ effective dose required for $50 \%$ reduction in acetolactate synthase enzyme activity, $b$ approximate coefficient of determination of nonlinear models with a defined intercept calculated as pseudo $r^{2}=1-($ sums of squares of the regression/corrected total sums of squares), $c$ probability level of significance of the nonlinear model, $d$ resistant factor $(\mathrm{RF})=\mathrm{I}_{50}$ of resistant $/ \mathrm{I}_{50}$ of susceptible cultivar 
Table 3 Total concentration of imazamox and its metabolites in leave and root extracts from resistant and susceptible cultivars of wheat at different times and application doses

\begin{tabular}{|c|c|c|c|c|c|c|c|c|}
\hline \multirow[t]{2}{*}{ Time } & \multirow[t]{2}{*}{ Cultivar } & \multirow[t]{2}{*}{ Dose $\left(\mathrm{g}\right.$ ai ha $\left.{ }^{-1}\right)$} & \multicolumn{2}{|l|}{ Imazamox } & \multicolumn{2}{|c|}{ Imazamox-OH } & \multicolumn{2}{|c|}{ Imazamox-glucose } \\
\hline & & & Leaves & Root & Leaves & Root & Leaves & Root \\
\hline \multirow[t]{6}{*}{$48 \mathrm{~h}$} & \multirow[t]{3}{*}{ Resistant } & 50 & $40.31 \pm 1.92$ & - & $14.08 \pm 2.00$ & - & $2.86 \pm 0.83$ & - \\
\hline & & 100 & $74.92 \pm 2.08$ & - & $27.55 \pm 1.65$ & - & $6.90 \pm 1.32$ & - \\
\hline & & 200 & $132.88 \pm 4.15$ & $9.76 \pm 0.34$ & $51.71 \pm 3.97$ & $7.42 \pm 1.06$ & $10.75 \pm 1.64$ & - \\
\hline & \multirow[t]{3}{*}{ Susceptible } & 50 & $58.39 \pm 1.32$ & - & - & - & - & - \\
\hline & & 100 & $127.57 \pm 2.94$ & - & - & - & - & - \\
\hline & & 200 & $253.03 \pm 3.07$ & $17.39 \pm 1.82$ & - & - & - & - \\
\hline \multirow[t]{6}{*}{$72 \mathrm{~h}$} & \multirow[t]{3}{*}{ Resistant } & 50 & $25.04 \pm 2.11$ & $4.86 \pm 0.84$ & $12.75 \pm 1.04$ & $4.32 \pm 0.23$ & $9.86 \pm 0.84$ & - \\
\hline & & 100 & $59.28 \pm 3.88$ & $10.02 \pm 0.99$ & $29.92 \pm 1.92$ & $9.53 \pm 1.20$ & $20.50 \pm 0.45$ & - \\
\hline & & 200 & $99.84 \pm 3.01$ & $19.01 \pm 0.10$ & $43.83 \pm 2.75$ & $17.02 \pm 1.03$ & $36.97 \pm 1.11$ & $1.03 \pm 0.02$ \\
\hline & \multirow[t]{3}{*}{ Susceptible } & 50 & $43.47 \pm 1.21$ & $22.93 \pm 0.28$ & - & - & - & - \\
\hline & & 100 & $91.74 \pm 0.97$ & $43.21 \pm 2.02$ & - & - & - & - \\
\hline & & 200 & $184.03 \pm 3.02$ & $80.36 \pm 2.54$ & - & - & - & - \\
\hline \multirow[t]{6}{*}{$96 \mathrm{~h}$} & \multirow[t]{3}{*}{ Resistant } & 50 & $21.06 \pm 1.21$ & $6.56 \pm 1.00$ & $15.97 \pm 0.87$ & $4.65 \pm 0.55$ & $18.94 \pm 1.97$ & - \\
\hline & & 100 & $47.11 \pm 1.67$ & $14.21 \pm 1.23$ & $36.15 \pm 2.96$ & $10.15 \pm 1.36$ & $41.49 \pm 1.04$ & - \\
\hline & & 200 & $80.65 \pm 2.19$ & $24.96 \pm 1.64$ & $60.45 \pm 2.14$ & $18.28 \pm 1.70$ & $89.90 \pm 3.01$ & $2.04 \pm 0.41$ \\
\hline & \multirow[t]{3}{*}{ Susceptible } & 50 & $23.92 \pm 1.10$ & $24.92 \pm 1.09$ & - & - & - & - \\
\hline & & 100 & $56.86 \pm 2.23$ & $51.38 \pm 2.01$ & - & - & - & - \\
\hline & & 200 & $99.38 \pm 2.58$ & $100.26 \pm 1.65$ & - & - & - & - \\
\hline \multirow[t]{7}{*}{$120 \mathrm{~h}$} & \multirow[t]{4}{*}{ Resistant } & 50 & $20.83 \pm 1.19$ & $7.28 \pm 0.43$ & $20.85 \pm 1.94$ & $4.96 \pm 0.54$ & $30.26 \pm 1.05$ & - \\
\hline & & 50 & $20.83 \pm 1.19$ & $7.28 \pm 0.43$ & $20.85 \pm 1.94$ & $4.96 \pm 0.54$ & $30.26 \pm 1.05$ & - \\
\hline & & 100 & $43.64 \pm 2.08$ & $16.53 \pm 0.89$ & $44.43 \pm 2.12$ & $11.21 \pm 0.25$ & $65.02 \pm 1.83$ & $2.72 \pm 0.22$ \\
\hline & & 200 & $75.85 \pm 2.20$ & $30.94 \pm 2.04$ & $79.83 \pm 1.78$ & $20.73 \pm 1.90$ & $118.92 \pm 3.06$ & $4.73 \pm 0.29$ \\
\hline & \multirow[t]{3}{*}{ Susceptible } & 50 & $15.06 \pm 1.02$ & $30.34 \pm 1.06$ & - & - & - & - \\
\hline & & 100 & $32.32 \pm 1.65$ & $68.12 \pm 1.93$ & $0.28 \pm 0.02$ & - & - & - \\
\hline & & 200 & $64.28 \pm 1.43$ & $120.37 \pm 3.00$ & $1.19 \pm 0.07$ & - & - & - \\
\hline
\end{tabular}

Metabolites expressed as imazamox microgram per gram $\left(\mu \mathrm{g} \mathrm{g}^{-1}\right)$ fresh weight, average values obtained by liquid chromatography-diode array detector and liquid chromatography-time-of-flight/mass spectrometer \pm standard deviation

"_" none detected

weight) was metabolised in the resistant cultivar at $120 \mathrm{~h}$ after treatment with $200 \mathrm{~g}$ ai of herbicide per hectare, while in the susceptible cultivar, only $0.64 \%$ was metabolised (1.19 $\mathrm{g} \mathrm{g} \mathrm{g}^{-1}$ of fresh weight).

The absorption and translocation of imazamox can also be studied by using this method and sampling the foliar part (leaves) and the root. Working in this way, it was observed that the susceptible cultivar, which was unable to metabolise, translocated imazamox from the leaves to the root throughout the experiment, especially after $72 \mathrm{~h}$. In contrast, in the resistant cultivar, the metabolites were the compounds translocated to the root. Translocation grew with the increase in dose and time. The difference between the two cultivars was the compound which translocated to the root, the toxic or the non-toxic form, that was determined by the metabolism studies. In both cultivars and with the same dose of imazamox applied, the amount of penetrated herbicide was the same, appearing as such, or metabolised, depending on the cultivar.

These results suggest that the resistant cultivar possesses a complementary resistance mechanism to acetolactate synthase enzyme mutation based on the metabolism of imazamox, and taking into account the degradation percentage, this mechanism is significant as it endows the cultivar with a higher resistance to this herbicide.

As indicated before, in the resistant cultivar, the imazamox metabolism occurred quickly at high doses of the herbicide $\left(200 \mathrm{~g}^{\mathrm{ai} \mathrm{h}} \mathrm{ha}^{-1}\right)$. At $48 \mathrm{~h}$ after the application of 50 or $100 \mathrm{~g}$ ai ha ${ }^{-1}$ dose, the imazamox was not metabolised. Metabolisation was detected only for doses equal to, or above, $200 \mathrm{~g}$ ai ha ${ }^{-1}$ of herbicide. Regarding the relationship with time, $120 \mathrm{~h}$ after application, at doses of 50 and $100 \mathrm{~g}$ ai ha ${ }^{-1}$, 66.61 and $67.21 \%$ of total penetrated imazamox in this cultivar were metabolised, respectively, while at a dose of 
Fig. 2 a Chromatograms obtained by liquid

chromatography-diode array detector analysis of extracts from susceptible and resistant cultivars of Triticum aestivum var. Pandora plants $120 \mathrm{~h}$ after treatment with $200 \mathrm{~g}$ ai ha ${ }^{-1}$ imazamox. b Extracted ion chromatograms (EICs) for $[\mathrm{M}+\mathrm{H}]^{+}$adducts of imazamox and metabolites obtained by liquid chromatography-time-of-flight/ mass spectrometer analysis of an extract from the resistant cultivar plants after herbicide treatment.

By comparison of both figures, it can be seen how the identification of the metabolites in liquid chromatography-diode array detector is performed based on the data obtained by liquid chromatography-time-of-flight/ mass spectrometer. By superimposing the two figures $(\mathbf{a}, \mathbf{b})$, the peaks in the chromatograms of Fig. 2a can be identified with their corresponding analytes, showing how in the resistant cultivar both metabolites appear

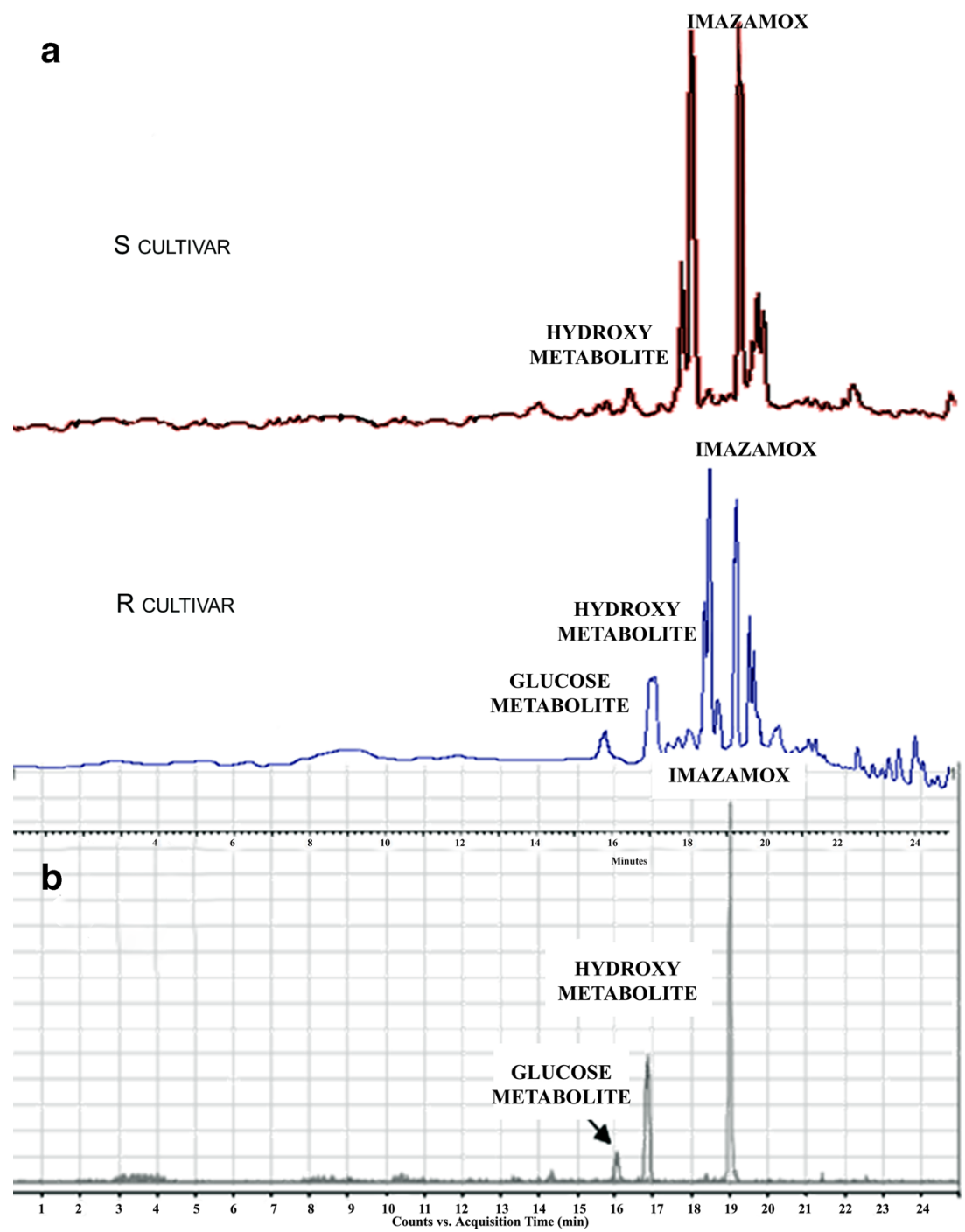

$200 \mathrm{~g}_{\text {ai ha }}{ }^{-1}, 67.74 \%$ was metabolised in the same amount of time. These results suggest that the metabolism occurs when the enzyme presents a high grade of inhibition due to the high dose of herbicide, put into operation when the enzyme is no longer operational. The metabolism reduces the amount of intracellular herbicide that can inhibit the acetolactate synthase enzyme, thus increasing the resistance to the herbicide compared to other populations with a single resistance mechanism (Rojano-Delgado et al. 2011).

Table 4 Effect of malathion on imazamox metabolism in leaves and root of resistant and susceptible cultivars (R and S) at $96 \mathrm{~h}$ after treatment with $200 \mathrm{~g}$ ai ha ${ }^{-1}$ of imazamox

\begin{tabular}{|c|c|c|c|c|c|c|c|c|}
\hline \multirow[t]{4}{*}{ Metabolites } & \multicolumn{8}{|c|}{ Amount of metabolites ( $\mu \mathrm{g} \mathrm{g}^{-1}$ fresh weight) } \\
\hline & \multicolumn{4}{|l|}{ - Malathion } & \multicolumn{4}{|l|}{ + Malathion } \\
\hline & \multicolumn{2}{|l|}{ Resistant } & \multicolumn{2}{|l|}{ Susceptible } & \multicolumn{2}{|l|}{ Resistant } & \multicolumn{2}{|l|}{ Susceptible } \\
\hline & Leaves & Root & Leaves & Root & Leaves & Root & Leaves & Root \\
\hline Imazamox & $47.11 \pm 1.67$ & $14.21 \pm 1.23$ & $56.86 \pm 2.23$ & $51.38 \pm 2.01$ & $98.39 \pm 1.93$ & $24.28 \pm 2.10$ & $67.28 \pm 2.29$ & $50.28 \pm 2.93$ \\
\hline Imazamox-OH & $36.15 \pm 2.96$ & $10.15 \pm 1.36$ & - & - & - & - & - & - \\
\hline Imazamox-glucose & $41.47 \pm 1.04$ & - & - & - & - & - & - & - \\
\hline
\end{tabular}

"-" none detected 
These results suggest that the resistant cultivar of T. aestivum var. Pandora present key resistance mechanisms that help to increase the resistance to the herbicide.

\subsection{Imazamox metabolism in combination with malathion}

The effects of malathion on imazamox metabolism in the resistant cultivar untreated and treated with malathion are shown in Table 4. The metabolism of imazamox in the resistant Pandora cultivar was inhibited in the presence of malathion as the metabolites in this cultivar disappeared. Conversely, imazamox was found to be increased in the leaves compared to the susceptible cultivar with malathion. This assay suggests that cytochrome P450 is involved in this detoxification mechanism and the hydroxylated metabolite is the precursor of the glucose-conjugated metabolite, the former being the product of a transition step to the final glucoseconjugated metabolite. This behaviour would explain why this metabolite also appears in the susceptible cultivar, even when the plant is fully affected and without any probability of survival. Thus, the hydroxyl group in this compound reacts with the anomeric carbon of the glucose group by condensation to form the glucose-conjugated metabolite (Shaner and O'Connor 1991).

\section{Conclusion}

The results obtained show that multiple mechanisms, target and non-target, are involved in the high-level resistance of the resistant Pandora cultivar to imazamox: (i) alteration of the acetolactate synthase enzyme produced by mutation in the amino acid sequence causing the loss of affinity by the binding (demonstrated indirectly by acetolactate synthase activity study with different herbicides and its relationship with the amino acid substituted); (ii) metabolism of imazamox, in which the cytochrome P450 is involved; and (iii) low translocation of imazamox to the root.

To maintain the sustainability of this new technology, an integrated management based on the rotation of other nonClearfield ${ }^{\circledR}$ crops, use of certified seeds and a large potential for weed control escapes must be implemented.

Although the metabolism of herbicides in wheat has been extensively studied in France (Mougin et al. 1990), this is the first study on the metabolism of imazamox in Clearfield ${ }^{\circledR}$ wheat cultivars made in the world.

Acknowledgments The authors are grateful to Spain's Ministry of Science and Innovation (MICINN) and FEDER program for funding this work through Project AGL-2010 16774 and CTQ2012-37428. F.P.C. is also grateful to the MICINN for a Ramón y Cajal contract (RYC-2009-03921).
Conflict of interest The authors have declared that no conflict of interest exists.

\section{References}

Aichele T, Penner D (2005) Adsorption, desorption, and degradation of imidazolinones in soil. Weed Technol 19:154-159. doi:10.1614/ WT-04-057R

Anderson JA, Matthiesen L, Hegstad J (2004) Resistance to an imidazolinone herbicide is conferred by a gene on chromosome 6DL in the wheat line cv. 9804. Weed Sci 52:83-90. doi:10.1614/ WS-03-055R

Bond JA, Stephenson DO, Barnes JW, Bararpour MT, Oliver LR (2005) Diclofop-resistant Italian ryegrass (Lolium multiflorum) control in imidazolinone-tolerant wheat. Weed Technol 19:437-442. doi:10. 1614/WT-04-199R

Bradford MM (1976) A rapid and sensitive method for the quantification of microgram quantities of protein utilizing the principle of protein dye binding. Anal Biochem 72:248-254. doi:10.1016/00032697(76)90527-3

Brady TM, Cross B, Doehner RF, Finn J, Ladner DL (1998) The discovery of imazamox, a new broad-spectrum imidazolinone herbicide. In: Baker DR, American Chemical Society (eds) Synthesis and chemistry of agrochemicals V. ACS Symposium Series, New Jersey, pp 30-37. doi:10.1021/bk-1998-0686.ch005

Bukun B, Nissen SJ, Shaner DL, Vassios JD (2012) Imazamox absorption, translocation, and metabolism in red lentil and dry bean. Weed Sci 60:350-354. doi:10.1614/WS-D-11-00182.1

Colquhoun J, Mallory-Smith C, Ball D (2003) Weed management in Clearfield wheat with imazamox. Oregon State University Extension Publication (EM8833), Corvallis

Cruz-Hipólito H, Osuna MD, Heredia A, Ruiz-Santaella JP, De Prado R (2009) Nontarget mechanism involved in glyphosate tolerance found in Canavalia ensiformis plants. J Agric Food Chem 57: 4844 4848. doi:10.1021/jf9003253

Duggleby RG, McCourt JA, Guddat LW (2008) Structure and mechanism of inhibition of plant acetohydroxyacid synthase. Plant Physiol Biochem 46:309-324. doi:10.1016/j.plaphy.2007.12.004

Fischer AJ, Bayer DE, Carriere MD, Ateh CM, Yim K (2000) Mechanisms of resistance to bispyribac-sodium in an Echinochloa phyllopogon accession. Pestic Biochem Physiol 68:156-165. doi: 10.1006/pest.2000.2511

González-Torralva F, Gil-Humanes J, Barro F, Domínguez-Valenzuela JA, De Prado R (2014) First evidence for a target site mutation in the EPSPS2 gene in glyphosate-resistant Sumatran fleabane from citrus orchards. Agron Sustain Dev 34:553-560. doi:10.1007/s13593013-0163-8

Han H, Yu Q, Purba E, Li M, Walsh M, Friesen S, Powles SB (2012) A novel amino acid substitution Ala-122-Tyr in ALS confers highlevel and broad resistance across ALS-inhibiting herbicides. Pest Manag Sci 68:1164-1170. doi:10.1002/ps.3278

Harir M, Frommberger M, Gaspar A, Martens D, Kettrup A, El Azzouzi M, Schmitt-Kopplin P (2007) Characterization of imazamox degradation by-products by using liquid chromatography mass spectrometry and high-resolution Fourier transform ion cyclotron resonance mass spectrometry. Anal Bioanal Chem 389:1459-1467. doi:10. 1007/s00216-007-1343-7

Kolkman JM, Slabaugh MB, Bruniard JM, Berry S, Bushman BS, Olungu C, Maes N, Abratti G, Zambelli A, Miller JF, Leon A, Knapp SJ (2004) Acetohydroxyacid synthase mutations conferring resistance to imidazolinone or sulfonylurea herbicides in sunflower. Theor Appl Genet 109:1147-1159. doi: 10.1007/s00122-004-1716-7 
Li D, Barclay I, Jose K, Stefanova K, Appels R (2008) A mutation at the Ala122 position of acetohydroxyacid synthase (AHAS) located on chromosome $6 \mathrm{D}$ of wheat: improved resistance to imidazolinone and a faster assay for marker assisted selection. Mol Breeding 22: 217-225. doi:10.1007/s11032-008-9168-4

Mellado MZ, Madariaga RB (2003) Pandora-INIA, nuevo cultivar de trigo harinero de primavera para Chile. Agric Téc (Chile) 63:319 322. doi:10.4067/S0365-28072003000300011

Mougin C, Cabanne F, Canivenc MC, Scalla R (1990) Hydroxylation and $\mathrm{N}$-demethylation of chlorotoluron by wheat microsomal enzymes. Plant Sci 66:195-203. doi:10.1016/0168-9452(90)90204-2

Ohba K, Minoura M, Safarpour MM, Picard GL, Safarpour H (1997) Method for the determination of imazamox and its two hydroxy and glucose conjugate metabolites in adzuki beans by capillary electrophoresis. J Pestic Sci 22:277-281. doi:10.1584/jpestics.22.277

Osuna MD, De Prado R (2003) Conyza albida: a new biotype with ALS inhibitor resistance. Weed Res 43:221-226. doi:10.1046/j.13653180.2003.00337.x

Pozniak CJ, Hucl PJ (2004) Genetic analysis of imidazolinone resistance in mutation-derived lines of common wheat. Crop Sci 44:23-30. doi:10.2135/cropsci2004.2300

Rainbolt CR, Thill DC, Zemetra RS, Shaner DL (2005) Imidazolinoneresistant wheat acetolactate synthase in vivo response to imazamox. Weed Technol 19:539-548. doi:10.1614/WT-03-215R1.1

Rodríguez-Suárez C, Ramírez MC, Martínez C, Nadal S, Martín A, Atienza SG (2009) Selection and molecular characterization of imidazolinone resistant mutation-derived lines of Tritordeum
HT621. Mol Breeding 23:565-572. doi:10.1007/s11032-0099256-0

Rojano-Delgado AM, Cruz-Hipolito H, De Prado R, Luque de Castro MD, Franco AR (2011) Limited uptake, translocation and enhanced metabolic degradation contribute to glyphosate tolerance in Mucuna pruriens var. utilis plants. Phytochemistry 73:34-41. doi:10.1016/j. phytochem.2011.09.007

Rojano-Delgado AM, Priego-Capote F, De Prado R, Luque de Castro MD (2013) Ultrasound-assisted extraction with LC-TOF/MS identification and LC-UV determination of imazamox and its metabolites in leaves of wheat plants. Phytochem Anal. doi:10.1002/pca. 2467

Seefeldt SS, Jensen JE, Fuerst EP (1995) Log-logistic analysis of herbicide dose response relationships. Weed Technol 9:218-227

Seefeldt SS, Zemetra R, Young FL, Jones SS (1998) Production of herbicide-resistant jointed goatgrass (Aegilops cylindrica) $\mathrm{x}$ wheat (Triticum aestivum) hybrids in the field by natural hybridization. Weed Sci 46:632-634

Shaner DL, O'Connor SL (1991) The imidazolinone herbicides. In: Duke SO (ed) Herbicide resistant crops. CRC Press, Boca Raton, p 289

Tan S, Evans RR, Dahmer ML, Singh BK, Shaner DL (2005) Imidazolinone-tolerant crops: history, current status and future. Pest Manag Sci 61:246-257. doi:10.1002/ps.993

Werck-Reichhart C, Hehn A, Didierjean L (2000) Cytochrome P450 for engineering herbicide tolerance. Trends Plant Sci 5:1360-1385. doi: 10.1016/S1360-1385(00)01567-3 